\title{
Shifting gender perceptions of female Nepalese students in Brisbane, Australia
}

\author{
Narayan Ghimire \\ Griffith University \\ mr.narayanghimire@gmail.com
}

\begin{abstract}
This article explores the changes in how Nepalese female students living in Brisbane, Australia, experience shifting expectations and perceptions of gender roles. It reviews a range of literature from migration studies, geography and humanities to investigate the interrelation between gender and migration, and the ways in which transforming gender relations among the Nepalese migrants in Australia might eventuate. Specifically, the article looks at how traditional gender roles are continued or discontinued by disclosing the lived experiences of a small cohort of Nepalese female students. A summary of qualitative interviews and ethnographic observations are used to highlight how their changing perspectives on traditional gender relations result from living in the changed socio-cultural settings of the host country, and the inherent challenges of implementing the changes in conventional interpretations of gender-based roles after returning to their home country.
\end{abstract}

\section{Introduction}

This research contextualises the lived experiences of Nepalese female students with regard to shifting gender relations after migrating to Brisbane, Australia. In recent years, there has been a substantial increase in the number of Nepalese students studying in Australia. According to the Australian Government Department of Home Affairs, 14,594 Nepalese students were granted visas to study in 2018, a considerable increase on only 9,871 in 2017. Despite the influence of the highly gendered socio-cultural settings of Nepalese society, which has eventually affected the migration decisions of Nepalese females, there is considerable progress in the trend of female student migration to Australia. There has been a marked rise in the number of Nepalese female students who have come to study in Australia, from 3,332 in the fiscal year 2017/18 to 4,792 in 2018 (Khatri 2019). The Queensland region is one of the most preferred education destinations for Nepalese students. Data from the Australian Government Department of Education (2018) reveal that 
there were a total of 3,742 Nepalese students in different institutions in Queensland between January and December 2018, which is a substantial rise from 2,409 in the previous year. This research article aims to explore the motivations and experiences of this increasing cohort of female migrants. The article aims to illuminate how knowledge has evolved in the research fields that investigate circumstances of gender-based migration from Nepal.

Significant research has been undertaken into Nepalese migration for employment and study opportunities. Bajracharya (2015) documents the changed perceptions of Nepalese migrant women in Portugal, who enjoy financial independence by finding employment or running a family business during the process of their amalgamation into Portuguese society. In most cases, migration from Nepal to European countries is provoked by factors such as economic opportunities, dreams of a better future career and aspirations for a better education (Saru 2015). Baral and Sapkota (2015) indicate that a better working environment, educational opportunities and better remuneration are strong motivating factors for Nepalese nurses to migrate abroad. However, these studies do not adequately address how students experience the shifts in gender roles that occur when migrating from traditional Nepalese society to more 'open' societies abroad. In Nepal, it is common for conservative family and patriarchal values to be sustained even for those living abroad. For Nepalese who are migrating permanently, their lives in host countries may change significantly. However, for Nepalese who are migrating only temporarily, for employment, education or family reasons, the stringent customs that reinforce patriarchal values often feature prominently in migration experiences especially for women. Through the literature reviewed here, this article identifies that there are significant changes in relation to how gender is perceived, and how Nepalese migrants' experiences of a new-found meaning of gender have been represented in previous research. From initial qualitative interviews and a review of the literature, this article argues that both males and females from Nepal challenge the traditional gender norms of Nepalese society while living in Australia. Despite the significance of literature that explores the relationship of gender and migration, I found a distinct gap, since the previous studies have not highlighted the shift in gender experiences in the specific context of Nepalese migration to Australia.

In order to elucidate the clear themes related to the context of gender and migration, the article is divided into five sections. The first section comprises a review of previous studies related to the interpretations of gender, linking to literature that specifically concentrates on the distribution of gender-based roles in Nepalese society. The second section analyses the impact of patriarchal social formation on Nepalese migration to foreign countries, specifically Australia. Next, the article briefly outlines the methods used in the study. The fourth section discusses the role of migration on gender awareness among Nepalese people, drawing from interviews and observations of the data. It suggests that shifts in family and relationship routines and behaviours significantly impact individual females who have migrated, as well as the left-behind family members in Nepal. The article concludes by highlighting that there are still distinct gaps in knowledge about the increasing flows of Nepalese migrants to Australia, and the sociocultural impacts of how gender, family and relationships are negotiated by these individuals in their new lives in Australia. 


\section{Gender, migration and sociocultural life}

For decades, there has been contestation about how to define and conceptualise 'gender'. Broadly speaking, the term 'gender' has been used in the social sciences to mark the difference between the social and biological interpretations of 'sex', and 'it encompasses both men's and women's active roles in society and their ideas about maleness and femaleness' (Carling 2005: 2). Many studies have strived to include gender as an inextricable part of social construction as well as a process of migration. Knapp, Muller and Quiros (cited in Dahal 2016) define gender to be a sociocultural construct of female and male identity that shapes how individuals live and relate to the world around them. Gender, they argue, is not a biological phenomenon, but rather learned in the course of living. Male or female identity is created not merely because of biological factors but because of a sociocultural construction of gender. Judith Butler, arguably one of the most seminal theorists on gender, states (2002: 10) that:

When the constructed status of gender is theorised as radically independent of sex, gender itself becomes a free-floating artifice, with the consequence that man and masculine might just as easily signify a female body as a male one, and woman and feminine a male body as easily as a female one.

Particularly in the context of migration, the differences between gender and biological sex complicated the situations of female and male migration patterns in terms of new-found routines, expectations and familial duties in host countries such as Australia.

In order to conceputalise gender in relation to the growing Nepalese-Australian migration patterns, an outline of how gendered experiences of migration has been studied helps to reveal the stark differences that females and males may experience. There is agreement that gender plays a significant role in migration experiences, with many researchers continuing to explore how conventions and traditions from a home country keep on changing before, during and after migration abroad. According to Holmes (2008: 130), 'social expectations about "ladylike" or "manly" behaviour do shift, as you will know from sometimes hearing older folk exclaim about how what youngsters are doing or wearing would not have been acceptable in their day'. It is important to understand the hierarchies, practices and sociocultural responsibilities that migrating people bring with them from their country of origin, and how these are used and adapted in their new place of residence. Robertson (2014) explores the consequences of dimensions of temporal migration process in Australia with a focus on how such migration strategies are formed by the state and experienced by the migrants. Importantly, Knowles (2003:15) identifies that the cultural settings in every society have numerous 'dos' and 'don'ts' for both male and female gender regarding dress and hairstyle, manners and behaviours. Such prescriptions are not naturally gleaned but instead are socially constructed.

There has been significant exploration of gender in relation to female experiences of migration. Many studies have attempted to explore the relationship between migration and gender in different ways. Martin (2018) examines the role played by gender in shaping the experience of early adulthood of Chinese women students and how they renegotiate the meanings of youth, feminine gender and intimate relationships while studying and living in Australia. According to Donato and colleagues 
(2006: 23), 'research on women, gender, and migration has fundamentally expanded and changed since it was last surveyed in IMR [International Migration Review] in 1984'.

This shift in focus has allowed a more diverse exploration of issues influencing migration decisions that revolve around gender and the relationship to sociocultural practices and conventions. For example, Vardazaryan (2016) charges that researchers have previously ignored the importance of gender relations in migration activities for several centuries. Similarly, Carling's (2005) study reveals that conventional interpretations of gender relations fail to include other types of relations between men and women - such as mothers and sons, brothers and sisters, and female employers and male employees. Vardazaryan and Carling both emphasise the necessity of expanding the scope of gender research so that it can accommodate the broader spectrum of gender relations in families as well as societies. A study by Pinnawala (2009) found that research into migration has not adequately addressed the issues of women's empowerment. Most of the studies in the field of gender and migration have depicted female migration as a part of male migration because they do not represent real experiences of females regarding gender and migration. Boyd and Grieco (2003:2) draw on the corresponding influence of gender and migration, and argue that 'the dual argument that gender is an integral part of the migration process and that theories of migration must incorporate it, has also influenced other areas of migration research'.

Migration provides the opportunity of social mobility, as well as emancipation from traditional gender norms. In the context of the new country, both men and women may find greater freedom in many areas of social, political, economic and religious life (Näre and Akhtar 2014). Similarly, Sharma (2011: 58) believes that as migration provides an opportunity to move away from traditional patriarchal societies, it is a source of empowerment for women since they are capable of earning money and building decision-making power in their daily lives. For migrant women from many countries of traditional gender relations, migration creates an opportunity for emancipation, since they have not only found a favourable sociopolitical environment but have also achieved financial independence. Many scholars have continued to support this argument that migration for women in many societies is an opportunity to escape from the boundary of patriarchal familial and social settings (Hondagneu Willis and Yeoh, cited in Hsu 2014). A study by Dahal (2016: 14) reveals that 'migration has also reshaped the way in which men and women accomplish gender identities'. Dahal implies that people migrating from one type of traditional society to an advanced and relatively more open society find new meaning in gender, which changes their previous understanding of it. These studies advocate the necessity of a new perspective in international migration research that gives space to the female migration process as equal to that of the male, and that recognises the lived experiences of migrant females. Most importantly, in the case of migration from countries that have societies with traditional gendered relations to advanced countries, as is the case with Nepalese migrants arriving in Australia, females' lived experiences have more to contribute to the new chapters in international migration research. 


\section{Gender discrimination and migration in Nepalese society}

Traditional family conventions in Nepalese society underpin the husband's and his family's objections to wives working away from home, which has forced women to work at home in order to maintain family prestige in the eyes of neighbours and relatives (Neupane 2017). Neupane analyses the context of discrimination of females in Nepalese society by the male members based on gender, and further explores how patriarchal social conventions in Nepal allow males to restrict female mobility within the institution of the household. It is quite disheartening that Nepalese women, even after the death of their husbands, are not allowed to remarry, and are also treated badly by their parents-in-law (Kharel 2016). Although there have been some changes in the traditional concept of gender roles, males are still regarded as the 'breadwinner' for the family, while their wives are considered to be responsible for household activities (Kharel 2016). This analysis forms the image of the subordinate positions of women in Nepalese society, where males have enjoyed dominant roles in all facets of family, as well as social, life at the cost of the independence of females. Bhadra and Shah (2007) have also examined the miserable condition of Nepalese females because, according to them (2007: 20), 'women in Nepal have neither the freedom of marital choice nor they have the fertility choice. Many women still go through unwanted pregnancy and childbirth due to lack of choice and decision-making.'

Due to the opportunity to live in different societies in the course of migration for study purposes, Nepalese females become aware of how traditional gender relations in their home society have prevented them from enjoying their autonomous status. This enables them to realise that the restructuring of conventional social patterns and formulating rules and regulations that encourage female participation in socioeconomic sectors is instrumental for the formation of society. Al-Bakr and colleagues (2017) insist on the necessity of reshaping hierarchical social structures. Since men have enjoyed a privileged position in all spheres of life, the path to gender equity requires them to reconsider the formation of their own personal as well as professional lives. Another study exhibits the discriminatory traditional gender norms that favour lucrative employment opportunities as well as provision of financial support for husbands, while wives are expected to remain close to home and perform certain assigned roles, such as cooking and serving food, as well as providing emotional care to family members (Compernolle 2017).

There is a need to briefly outline the stringent hierarchies and powers associated with gender in Nepalese society before turning to the restrictions (and recent adjustments) on female migration opportunities. Gender determines the division of domestic as well as social responsibilities in Nepalese society, and females are prevented from participating in productive and community work because of their gender (Khadka 2014: 17). The mobility of Nepalese women, as Valentin (2015) notes, is more restricted in comparison with that of men, and is tied up with a set of expectations regarding suitable behaviour and future pathways for women. In Nepalese society, the majority of women live with the man's family after marriage, and the family line is continued through the husbands - wives take the family name of the husband which is transferred to their children (Dahal 2016). Bhadnari (2015) opines that Nepalese society, because of a lack of opportunity to proper education, has the dominance of conservative assumptions which gives space to discriminatory 
gender relations. In Nepal, males tend to engage in work outside the home since they are assigned the responsibility of providing financial support to other family members, whereas females' roles are largely confined within the domestic spheres (and are thus discouraged from working outside of the home). Sharma and colleagues (2014) found that females constituted a significantly lower percentage of international migration from Nepal, registering only 12 per cent, even in the interval between 2001 and 2011 when there was a marked increase in the trend of migration from Nepal. The findings of this study indicate gender-based discrimination with regard to migration from Nepal, as there was a vast gap between the percentage of males and females who migrated.

Despite many political changes, most Nepalese women have not experienced emancipation from the yoke of traditional gender norms and roles, which require them to perform gender-based roles in the name of continuing cultural and religious values - for example, not leaving the house without a male family member such as their husband (Neupane and Chesney-Lind 2014). The primary meaning and purpose of females' lives in Nepalese society is marriage, and the tragedy is that they do not have freedom to make their own choice (Bhadra and Shah 2007). Due to the dominance of conventional and superstitious beliefs that value male supremacy, females in Nepalese society have been prevented from making their own choices even in the most sensitive cases, such as education and marriage. Bhandari's (2019) finding reveals that people in Nepal, mostly girls, are forced to marry early due to family pressure, as well as superstitious beliefs in the society. In most cases, they are controlled by their fathers before marriage; in many societies, females are still discouraged from choosing their life partners because it is believed that fathers have the right to make decisions on behalf of them. Khadka (2014: 43) states that, 'Nepal's patriarchal society gives men a greater social and economic status than women. The role of women in decision- making is negligible except in raising children and household management.' Both Bhandari and Khadka are of the opinion that females in Nepal are deprived of the opportunity to live independently, their role is restricted within household chores and they have no opportunity of being involved in decision-making activities. Therefore, we can infer that gender has distinct impacts upon the process of migration from Nepal. These impacts are unequally distributed between women and men.

While it is obvious that traditional gender relations shape the ways in which female Nepalese migrants engage with migration, it is through migration that women are able to challenge the patriarchal norms and structures outlined above. Bajracharya (2015) states that it is due to patriarchy that Nepalese could migrate mostly by accompanying their husbands and other members of their family, as it has restricted females' ability to work outside their homes and limited their movement to activities within the household. Adhikari's (2010) research into Nepalese females migrating to the United Kingdom for nursing employment shows that although they had to face challenges as migrants in a foreign land, this had a positive impact on their status both in the family and in society due to the traditionally gendered perceptions of 'nursing' as a feminine profession. Shakya (2014:232) also analysed the changing gender status of females, stating that, 'The proportion of females migrating to Europe is much higher than males, possibly due to education, employment or marriage.' In most cases, migration to European countries is provoked by factors such as economic opportunity, dreams of a better future 
career and aspirations for a better education (Saru 2015). Bhadra (2007: 14) finds that the positive aspects of foreign employment opportunity lead towards the path of independence, suggesting that, 'The opening of opportunities for Nepalese women in the global labour market has transformed the image of women from dependants to economic actor. 'In a nutshell, the studies reviewed above reveal that secure career opportunities and economic independence have become the major attractions for female migration from Nepal. They also point out that the increasing trend of female migration for career reasons has made a significant contribution in changing the image of Nepalese society because this has made them able to not only live independently, but also to change the perceptions of family and society towards them.

\section{Research methods}

This research is qualitative in nature and exploratory in design. The main motivation for the study was to gain new insights into the gender dimension of student migration from Nepal, based on the lived experiences of Nepalese female students who were accompanied by their husbands in Australian society - that is, with the female as the primary visa holder and the male as a dependant on her visa. They have been studying either for a Bachelor's or Master's degree at different institutions in Queensland, Australia since 2017/18. The data-collection process focused on semi-structured interviews with female Nepalese students who were studying at different colleges and universities in Brisbane, Australia. The research project was granted ethics approval by the author's university and each participant was given an information sheet and consent form to read and consider before agreeing to participate in the interview. All participants were above 18 years old and were residing in Brisbane, Queensland. As this research is exploratory in nature, it did not have any rigid structured interview patterns. Hence, participants participated in semi-structured interviews.

In addition, the research drew on my own position as an 'insider researcher', as a Nepalese student and temporary migrant living in Brisbane. A study by Taylor (2011) suggests that familiarity and previous knowledge of the research context play a role in deriving different as well as detailed answers from the participants. Voloder (2014) suggests that someone who has the status of both migrant and scholar is considered suitable for the insider position in migration research. Therefore, apart from sharing the same sociocultural background, similarity of migration status and relevant professional background encouraged me to choose the insider position for this research. It is important to note that I have more than ten years' experience in the field of student counselling as a study abroad consultant, which I have continued on a part-time basis in an education consultancy in Brisbane; this informed how potential participants were recruited, in line with the university ethics clearance. My professional engagement in an education consultancy in Brisbane was very helpful, since I had the opportunity to interact with many Nepalese students, and some of the interactions could contribute as an important data source, with the students' informed consent. Méndez (2013) defines this as an 'ease of access to data', since the researcher reflects on their own experiences as the 
source based on which they investigate a particular phenomenon. A researcher researching among their own community always enters the world of known circumstances that both groups share, and this gives the feeling that the researcher is part of the researched. England (1994, p. 251) suggests that 'we do not conduct fieldwork on the unmediated world of the researched, but on the world between us and the researched'. Therefore, some of the female students who visit for studyrelated services were selected for semi-structured interviews. I selected six participants in their late twenties for interviews, most of which went for approximately 30 minutes. All of the participants were informed about the research project. In addition, my ethnographic reflections recount responses of group participants during some formal or informal occasions, such as Nepali festivals, birthdays and social gatherings.

The female participants in my research, who have come from the same sociopolitical context, are the really important actors in the gendered worlds of Nepalese society. This is because they are the educated people who are capable of contributing to socio-political changes and, most importantly, they also have the experiences of living in both the sending and receiving societies. The opportunity of living and studying in the host society will help them to investigate gender discrimination when they return to their home country, and will enable them to identify the inherent factors responsible for unequal gender relations, and also to contribute to the elimination of gender-based discrimination.

\section{Migrating to Brisbane}

Throughout the interviews with participants, and from my own personal experiences and observations, there were drastic shifts in gender roles, perceptions and expectations for Nepalese female students who had recently migrated to Brisbane. The theme of negotiating changing gender roles was the most visible commonality in the responses of all the participants recorded. An analysis of each participant's narration, as well as my personal observations, revealed that in many ways they have experienced a kind of emancipation from traditional gender-based roles both in domestic and social life after coming to Australia, which symbolises the discontinuing of gender roles. Subana, one of the respondents I interviewed, found a completely different conception of gender after coming to Australia because in this country both males and females are considered equal and have equal opportunities to work. According to her, in Nepal females should remain at home and perform tasks such as cooking and agriculture-related work, while males are expected to go out into the world and earn money. Coming from a country with a high degree of gender disparity, where females are restricted from going out after dark, it was a totally different experience for her when she saw females going to work even at night.

From among the responses collected, the proportions of their conversations that resembled their positionality with regard to the interpretation of gender relations based on their lived experiences of two different societies were considered for analysis of the theme of shifting gender experiences. Sumitra also had similar opinions regarding the difference of gender relations between Australia and Nepal. The significant difference according to her is that there are many dos and don'ts for females: for example, they have to face many questions both in their parents' home and in their in-laws' home should they come home late in the evening. Conversely, 
in Australia, as she has been living only with her husband, she is not required to face such a situation:

I have not felt this in Australia, and it might be because I am living only with my husband. Since my father-in-law and mother-in-law are not here, I can speak straightforwardly to my husband, and husbands these days are not like in the past.

Laxu, another participant who came to Australia on a student visa in July 2017, was accompanied by her husband after seven months as a dependant. She expressed mixed opinions about her experience as a daughter-in-law in Nepal and the changes that she experienced after coming to Australia. She came alone initially, and said she felt lonely in the absence of her husband and parents-in-law. She had feelings of missing the guidance of her husband as well as her parents-in-law, as they were her guardians. At the same time, she also felt relieved as she did not feel pressure from her parents-in-law after coming to Australia. For example, although she had a job in Nepal, she also had to manage her time for other household tasks as she was a daughter-in-law. But after coming to Australia, she no longer felt that pressure, since she could now make her own choices.

After coming to Australia, Laxu had the experience of living only for her own benefit, since she had feelings of emancipation from the burden of performing as a daughter-in-law and her activities were no longer controlled by the norms of a patriarchal society. It was due to the impact of prevailing cultures in Nepal that she had to play the role of typical wife and daughter-in-law. Conversely, she has found her husband totally different because in Nepal they were living within the boundaries of a conventional husband and wife scenario, but here they have become friends. While in Nepal, her husband would listen to his parents more than her and would be anxious about social expectations.

To further contextualise these interview reflections, the socio-political situation in Nepal greatly informs how and why Nepalese people migrate to areas like Brisbane. Over the past two decades, there have been considerable changes in patterns of gendered migration from Nepal. The political movement in 1990 overthrew the three-decades-long Panchayat system in Nepal and this was followed by many other social revolutions, which eventually had a positive impact on the growth of Nepalese student migration to different countries. India has remained the most popular destination for student migrants from Nepal. However, in recent years other destinations, such as Australia, the United States and the United Kingdom, have been quite popular among Nepalese students. Valentin (2015: 321) states that, 'The relaxation of emigration rules combined with 10 years of armed conflict between government forces and Maoist insurgents (1996-2006) and the ensuing post-conflict situation characterised by political instability contributed to increase in emigration from Nepal.' This indicates that, apart from introducing favourable emigration policies, the adverse political environment in Nepal was also a significant factor that forced Nepalese students to find alternative study destinations. The vulnerable political atmosphere coincided with some affirmative changes in migration regulations, and because of this Nepalese students started travelleing to different countries for study opportunities.

After 2007, there was a noticeable increase in the flow of Nepalese students who chose to study with different Australian education providers. O'Keefe's (2007) study shows that there were 2,884 Nepalese students who commenced their studies 
in various institutions of Australia in 2007, a 504 per cent increase compared with the record of the previous year. In the case of Nepalese students, Australia has been one of the most preferred study destinations. The statistics recorded by the Department of Home Affairs (2014) state that 36,940 Nepalese-born people were living in Australia, seven times more than in 2006. According to the Department of Education and Training, a total of 15,219 Nepali students were studying in different regions in Australia. Among them, 61.2 per cent were males while female participation was only 38.8 per cent (Ferguson and Sherrell 2019). To reinforce the shifts that are taking place, it is crucial to understand that it is only a recent socially accepted phenomena that a Nepalese woman will be the primary visa holder, and that her male partner (almost always their husband) accompanies her as a dependant on her visa. In the cases where a young female is not married prior to intended migration, a marriage usually occurs immediately before departure to facilitate outward migration. In this vein, the shift to a female being the primary visa holder is a significant step forward in emancipatory opportunities for study, work, and leisure while they are abroad. Most $\backslash$ participants in this research who came to Australia in the student category were accompanied by their husbands, which indicates a positive change regarding female migration for study opportunities. The other participants changed their status as students after coming to Australia. However, none of them came to Australia before their marriage.

Notwithstanding the positive development in the flow of migration from Nepal for study opportunity, historically females have had - and still have - far less freedom to make migration choices compared with males because of the patriarchal social patterns. Boyd and Grieco (2003) argue that gender relations and hierarchical family circumstances have impacted the migration of women because family circumstances are the points of origin for female subordination to male authority. They begin to learn about the different gender roles for sons and daughters, as well as husbands and wives, from the family environment in which they live in. Ghosh (2009: 20) believes that, 'The nature of gender relations in the sending society is a crucial determinant of both the ability of women to migrate and the pattern of migration'. He implies that in many migrant-sending societies, gender roles - which are socio-cultural constructions - still shape female migration patterns. However, after they migrate to a different society, they slowly and gradually change their interpretations of gender norms due to the influence of sociocultural contexts in the host society. This has certainly been shown to be the case in the data I have collected, and this came across strongly in all of the interviews. All the participants who were interviewed revealed that, after coming to Australia, they had been liberated from the yoke of patriarchy, which caused them to perform traditional gender roles. The common perception among the participants was that living in Australian society had changed their previous understanding of the meaning of gender roles.

After spending several months, and even years, living in Australia, both males and females from Nepal are likely to perceive different meanings and interpretations of their gender roles, which are likely to pose challenges to the traditional gender relations and patterns upon their return home to Nepal. Subana, one of the participants I interviewed, was quite confident that female student migration from Nepal contributed to the change in traditional gender perceptions in her home country, since 
even those who did not do anything in Nepal have changed to some extent by observing or learning from here. Even after going back to Nepal, though it may take three or four years, they can certainly bring change within that time.

Dahal (2016) observed changed perceptions of gender among Nepalese men in Portugal as they put fewer restrictions on women, symbolising 'undoing gender' since gender-based roles - particularly in the case of females - are considered compulsory in Nepalese society. In many cases, they have to compromise with dual gender roles throughout their lives - for instance, that expected by the conventional society back home and that offered by the open society in which they are living, with a lesser degree of gender discrimination. This is in line with the findings of this study. For many Nepalese student migrants, in the course of living in a new society they begin to adopt new-found meanings of gender in day-to-day life, including shifting feminine and masculine practices, and domestic roles and responsibilities being adapted into new routines and configurations. However, as they go back to their home society, they may have to continue traditional gender roles because of the obvious differences of their sociocultural setting. Anita appears confident enough to reject some of the traditional gender roles after returning to her home country; however, since she is aware of the unequal role distribution for males and females, she also accepts that she will not be able to follow the Australian pattern of living. She carries a feeling of 'in-betweenness' regarding how she will live after returning to her country of origin.

The patricentric family conventions and patrilocal residence pattern in Nepalese society reveal that females face different types of restrictions on their mobility. This begins at their parents' home and continues with some added limitations when they go to their husband's home after marriage. They are deprived of the opportunities to perform activities without permission, either within the family or in the community. Conversely, their new-found awareness of their mobility, which they have developed as a result of living in Australian society, has given them the confidence to live independently in both the domestic and social sectors.

\section{Conclusion}

This article has concentrated on the theme of how perceptions of gender relations change among Nepalese female students due to living in the sociocultural context of life in Brisbane, Australia. The review of different groups of literature relevant to gender and migration implies that migration decisions of Nepalese females are largely influenced by the prevailing concept of gender relations in Nepalese society. However, after living in foreign societies, they become aware of gender equality, and have feelings of emancipation from the burden of traditional gender roles that they had been performing. Subana's experience after living in Australian society reveals the same as she says:

I have been feeling far more freedom in Australia than in Nepal. Since we are only husband and wife here, it has been quite easy for us to decide whatever we want, but when we were in Nepal, we would have to consult all, such as Dad, Mum and parents-in-law as being married.

This research indicates that Nepalese female students who have migrated to Australia accompanied by their husbands as dependants have developed a new 
awareness of gender relations, and this has had a significant impact on how they will choose to live upon returning to the home society. As Sumitra stated:

Females, after knowing everything about what is their freedom and what is their wishes in the course of living in Australia, will not obviously want to embrace the old conservative culture which discriminates between sons and daughters; nobody wants to live being dominated.

Such comments from the participants illustrate the importance of understanding shifts in gender roles, expectations and experiences at all stages in migration. Understanding the dramatic shifts of females can be an important resource for the respective government authorities in Nepal and Australia, as well as for future gender and migration researchers. In addition, education consultancies in Nepal can also utilise study abroad as a reference for counseling Nepalese students regarding how a changed sociocultural context of living can change their perceptions about traditional gender relations.

This research will provide a solid platform for future research on gender and migration from Nepal to Australia. This is a pilot study, and there is room for further qualitative insights into the lived experiences of migrants, especially from Nepal but from all over Asia, as the increasing flow of international students to Australia continues. It will be important to understand the wider web of gender relations that is being negotiated, affected and transformed though the international mobility of students from Nepal. This is an extremely under-explored area of research, and this pilot study offers a brief scoping of the current limitations and gaps of knowledge.

Narayan Ghimire is a researcher in gender and migration. Prior to commencing higher degree research at Griffith University, he was engaged in the teaching profession in different tertiary institutions of Nepal for more than a decade. During his higher degree research at Griffith University, he also served as a research assistant for a research project entitled 'Material Mobilities: The role of Materials in the Perceptions, Experiences, and Practices of Global Mobility’.

\section{References}

Adhikari, R. 2010, 'The dream-trap: Brokering study abroad and nurse migration from Nepal to the UK', European Bulletin for Himalayan Research, vol. 35, no. 36, pp. 122-32.

Al-Bakr, F., Bruce, E. R., Davidson, P. M., Schlaffer, E. and Kropiunigg, U. 2017, 'Empowered but not equal: Challenging the traditional gender roles as seen by university students in Saudi Arabia, FIRE: Forum for International Research in Education, vol. 4, no. 1, p. 3.

Bajracharya, M. 2015, 'Nepalese women migrants in Portugal and their experience with socio-cultural integration, $\mathrm{PhD}$ thesis, Instituto Universitário de Lisboa, Lisboa.

Baral, R. and Sapkota, S. 2015, 'Factors influencing migration among Nepalese nurses', Journal of Chitwan Medical College, vol. 5, no. 2, pp. 25-9.

Bhadra, C. 2007, International labor migration of Nepalese women: Impact of their remittances on poverty reduction. Working Paper Series No. 44, Asia-Pacific 
Research and Training Network on Trade. Available from https:/gsdrc.org/ document-library/international-labour-migration-of-nepalese-women-the-impactof-their-remittances-on-poverty-reduction [20 September 2020].

Bhadra, C. and Shah, M. T. 2007, Nepal: Country gender profile. Kathmandu: JICA. Bhandari, N. R. 2019, 'Early marriage in Nepal: Prospects for schoolgirls', Journal of International Women's Studies, vol. 201, no. 3, pp. 88-97.

Bhadnari, P. R. 2015, 'Cultural identity of Nepalese immigrants living in Oslo', Master's thesis, School of Mission and Theology, Oslo. Available from https:// vid.brage.unit.no/vid-xmlui/bitstream/handle/11250/286485/Bhandari $\% 2 \mathrm{c} \%$ 20Parshu \%20Ram \% 2c\% 20master\%20thesis\%20v\%c3\%a5r\%202015.pdf? sequence $=1 \&$ isAllowed $=y$ [21 September 2020].

Boyd, M. and Grieco, E. 2003, Women and migration: Incorporating gender into international migration theory, Migration Information Source, vol. 1, no. 35, p. 28.

Butler, J. (2002). Gender trouble: Tenth anniversary edition, London: Routledge.

Carling, J. 2005, 'Gender dimensions of international migration', Global migration perspectives, no. 35, pp. 1-26.

Compernolle, E. 2017, 'Spouses crossing borders: Husbands? International migration and the marital relationship, $\mathrm{PhD}$ thesis, University of Michigan. Available from https://deepblue.lib.umich.edu/handle/2027.42/140806 [21 September 2020].

Dahal, S. 2016, 'Perception and practice of gender among Nepalese in Portugal: a male perspective', $\mathrm{PhD}$ thesis. Available from https://repositorio.iscteiul.pt/bitstream/10071/ 11601/1/THESIS_submission_FINALSanjeev\%20pdf.PDF [21 September 2020].

Donato, K. M., Gabaccia, D., Holdaway, J., Manalansan IV, M. and Pessar, P. R. 2006, 'A glass half full? Gender in migration studies', International Migration Review, vol. 40, no. 1, pp. 3-26.

England, K. V. 1994, 'Getting personal: Reflexivity, positionality, and feminist research', The Professional Geographer, vol. 46, no. 1, pp. 80-9.

Ferguson, H. and Sherrell, H. 2019, 'Overseas students in Australian higher education: A quick guide', Parliament of Australia. Available from https://www.aph.gov.au/ About_Parliament/Parliamentary_Departments/Parliamentary_Library/pubs/rp/ rp1819/Quick_Guides/OverseasStudents [21 September 2020].

Ghosh, J. 2009, Migration and gender empowerment: Recent trends and emerging issues, Geneva: United Nations. Available from https://mpra.ub.uni-muenchen.de/ 19181/1/MPRA_paper_19181.pdf [21 September 2020].

Holmes, M. 2008, Gender and everyday life. London: Routledge.

Hsu, W. S. 2014, 'Gender, marriage migration and the cultural politics of multiculturalism in Taiwan', $\mathrm{PhD}$ thesis, University of Pennsylvania.

Khadka, S., 2014, 'Gender roles and migration: A qualitative field study of Nepalese migrants in Berlin', Master's thesis, Available from https://scholar.google.com.au/ scholar?hl=en\&as_sdt $=0 \% 2 \mathrm{C} 5 \& \mathrm{Qq}=\mathrm{Khadka} \% 2 \mathrm{C}+\mathrm{S} .+\% 282014 \% 29 .+$ Gender + roles+and+migration $\% 3 \mathrm{~A}+\mathrm{a}+$ qualitative+field+study+of+Nepalese+migrants +in+Berlin [21 September 2020].

Kharel, A. 2016, 'Female labor migration and the restructuring of migration discourse: a study of female workers from Chitwan, Nepal', PhD thesis, Kansas State University. 
Khatri, R. 2019, '14,594 Australian visas granted to Nepalese students in six months'. Available from https://www.southasia.com.au/2019/01/31/14594-australian-visasgranted-to-nepalese-students-in-six-months [31 January 2019].

Knowles, P.D. 2003, 'Gender across cultures: The immigration experience - Bulgarian immigrants in South Florida'. PhD thesis, Florida International University. Available from https://digitalcommons.fiu.edu/dissertations/AAI3057594 [21 September 2020].

Martin, F. 2018, 'Overseas study as zone of suspension: Chinese students renegotiating youth, gender, and intimacy', Journal of Intercultural Studies, vol. 39, no. 6, pp. 688-703.

Méndez, M. 2013, 'Autoethnography as a research method: Advantages, limitations and criticisms', Colombian Applied Linguistics Journal, vol. 15, no. 2, pp. 279-87.

Näre, L. and Akhtar, P. 2014, 'Gendered mobilities and social change: An introduction to the special issue on gender, mobility and social change', Women's Studies International Forum, no. 47, pp. 185-90.

Neupane, G. 2017, Sexual harassment and reproduction of patriarchy in public space in Nepal, PhD thesis, University of Hawai'i at Manoa. Available at: http://search.proquest.com.libraryproxy.griffith.edu.au/docview/2030530690? accountid=14543 [21 September 2020].

Neupane, G. and Chesney-Lind, M. 2014, 'Violence against women on public transport in Nepal: Sexual harassment and the spatial expression of male privilege', International Journal of Comparative and Applied Criminal Justice, vol. 38, no. 1, pp. 23-38.

O’Keefe, B. 2007, 'Huge increase in Nepalese students', The Australian, 18 November. Available from http:/www.theaustralian.com.au/higher-education/hugeincrease-innepalese-students/story-e6frgcjx-1111114904963 [21 September 2020].

Pinnawala, M. 2009, 'Gender transformation and female migration: Sri Lankan domestic workers negotiate transnational household relations', PhD thesis, Institute of Social Studies, The Hague. Available from https://core.ac.uk/download/pdf/ 18514809.pdf [21 September 2020].

Robertson, S. 2014, 'Time and temporary migration: The case of temporary graduate workers and working holiday makers in Australia', Journal of Ethnic and Migration Studies, vol. 40, no. 12, pp. 1915-33.

Saru, B. 2015, 'Migratory experiences of Nepalese families with small children currently in Norway', Master's thesis, School of Mission and Theology, Oslo. Available from https://vid.brage.unit.no/vid-xmlui/handle/11250/286443 [21 September 2020].

Shakya, K. 2014, 'Changing gender status: Achievements and challenges', Population Monograph of Nepal, no. 2, pp. 221-71.

Sharma, R. 2011, Gender and international migration: The profile of female migrants from India, Social Scientist, vol. 39, nos 3/4, pp. 37-63.

Sharma, S., Pandey, S., Pathak, D. and Sijapati-Basnett, B. 2014, State of migration in Nepal, Kathmandu: Centre for the Study of Labour and Mobility.

Taylor, J. 2011, 'The intimate insider: Negotiating the ethics of friendship when doing insider research', Qualitative Research, vol. 11, no. 1, pp. 3-22.

Valentin, K. 2015, 'Transnational education and the remaking of social identity: Nepalese student migration to Denmark', Identities, vol. 22, no. 3, pp. 318-32. 
Vardazaryan, G. 2016, 'Gender, migration, and practices of political participation in Lethbridge', PhD thesis, University of Lethbridge.

Voloder, L. 2014, 'Introduction: Insiderness in migration and mobility research: Conceptual considerations', in L. Volder and L. Kirpitchenko (eds), Insider research on migration and mobility: International perspectives on researcher positioning. Aldershot: Ashgate, pp. 1-17. 